\title{
VEIKSMINGOS VAIKŲ IR JAUNIMO SVEIKATOS STIPRINIMO POLITIKOS PRIEMONÉS FIZINIO AKTYVUMO BEI SVEIKOS MITYBOS SRITYJE VIETOS BENDRUOMENIŲ SUINTERESUOTŲ GRUPIŲ POŽIŪRIU
}

\author{
Aldona Jociutè \\ Mykolo Romerio universiteto Politikos ir vadybos fakulteto \\ Politikos mokslų institutas \\ Valakupių g. 5, LT-10101 Vilnius, Lietuva \\ Elektroninis paštas joaldona@mruni.eu \\ Gintarė Petronytė \\ Mykolo Romerio universiteto Politikos ir vadybos fakulteto \\ Politikos mokslų institutas \\ Valakupių g. 5, LT-10101 Vilnius, Lietuva \\ Elektroninis paštas ginpetr@mruni.eu \\ Pateikta 2015 m. kovo 30 d., parengta spausdinti 2015 m. gegužès 4 d.
}

DOI:10.13165/SPV-15-1-8-06

\section{Santrauka}

Šiame straipsnyje analizuojamas vietos bendruomeniu suinteresuotu grupiu (politikos formuotoju bei sprendimu priemejju, administratoriu ir praktiku) požiüris ì veiksmingas vaiku ir jaunimo sveikatos stiprinimo politikos priemones fizinio aktyvumo bei sveikos mitybos srityje. Kokybinis tyrimas, taikant pusiau struktūrizuota interviu, buvo atliktas dalyvaujant Klaipédos miesto, Kauno ir Jurbarko rajonu savivaldybiu instituciju atstovams 2013 metu liepos-rugsejo mèn., igyvendinant tarptautini sveikos mitybos ir fizinio aktyvumo skatinimo vietos bendruomenese projekta (angl. Promoting healthy eating and physical activity in local communities, HEPCOM). Tyrimo duomenimis, suinteresuotu grupiu atstovai planuodami vaiku ir jaunimo sveikatos stiprinimo veikla fizinio aktyvumo ir sveikos mitybos srityje dažniausiai taiko politikos ir sprendimu priemimo, strateginio planavimo, veiklos planavimo ir jos igyvendinimo priemones, tačiau jie susiduria su vertinimo priemoniu taikymo kliūtimis. Pagrindinès prielaidos, bütinos vietos bendruomenèse vystyti vaiku ir jaunimo sveikatos stiprinimo veikla, yra kryptinga šalies sveikatos politikos strategija ir nustatyti 
prioritetai, tarpinstitucinis bendradarbiavimas, tarpsektorine veikla, informacijos prieinamumas apie gerosios praktikos intervencijas ir ju vertimo i̇rankius, taip pat žmogiškieji, finansiniai bei informaciniai ištekliai.

Reikšminiai žodžiai: sveikatos stiprinimo politika, fizinis aktyvumas ir sveika mityba, vaikai ir jaunimas, suinteresuoti asmenys.

\section{Ivadas}

Daugelyje šalių lètinès neinfekcinès ligos tapo prioritetine sveikatos problema, o jos sprendimui politikai ėmèsi kryptingų veiksmų, kurie leistų suvaldyti šių ligų paplitimą ir keliamą naštą. Pasaulio sveikatos organizacija, atkreipusi dèmesị ị lètinių neinfekcinių ligų rizikos veiksnius, ypač nesveiką mitybą ir fizinị neaktyvumą, ragina šalis taikyti ịrodymais pagrịstas ir efektyvias sveikatos stiprinimo ir prevencijos intervencijas ${ }^{1}$. Šias intervencijas siūloma taikyti bendruomenėse, kuriose paplitę lètinių neinfekcinių ligų rizikos veiksniai, o igyvendinant jas būtinas bendruomenès narių dalyvavimas, politikų parama, tarpsektorinė veikla ir bendradarbiavimas su nevyriausybinėmis organizacijomis, privačiu sektoriumi² ${ }^{2}$. Atsižvelgiant, kad lètinių neinfekcinių ligų rizikos veiksniai pradeda formuotis ankstyvoje vaikystejje, pabrěžiama vietos valdžios institucijų veiksmai, skatinantys sveiką mitybą, fizinį aktyvumą bei palaikantys nutukimo prevenciją ${ }^{3}$.

Lietuvos Respublikos Aukščiausiajai Tarybai - Atkuriamajam Seimui patvirtinus nacionalinę sveikatos koncepciją, prasidejo nacionalinès sveikatos politikos formavimas, lygiagrečiai buvo formuojama ir vaikų sveikatos stiprinimo politika, kurią igyvendinant ịtraukiamos bendruomenių tarybos, savivaldybių gydytojų tarnybos, švietimo, sveikatos, socialinių, vidaus reikalų sistemų struktūros, taip pat sveikatą stiprinančios mokyklos, nevyriausybinès organizacijos ir aktyvūs piliečiai ${ }^{4}$. Pažymètina, kad sveikatos stiprinimo veiksmai vietos lygiu igyvendinami atsižvelgiant $i$ šalies bei tarptautinių institucijų priimtus sprendimus ir igyvendinamą sveikatos politiką, be to, vietos valdžios institucijos ar bendruomenès nusistato sveikatos stiprinimo veiklos prioritetus, atsižvelgiant i finansinius, žmogiškuosius ir kitus išteklius. Vystant bendradarbiavimą svei-

1 World Healh Organization. Vienna declaration on Nutrition and Noncommunicable diseases in the Context of Health 2020. WHO Ministerial Conference on Nutrition and Noncommunicable Diseases in the Context of Health 2020 [interaktyvus]. 4-5 July 2013, Vienna [žiürèta 2015-01-08]. $<$ http://www.euro.who.int/_data/assets/pdf_file/0003/234381/Vienna-Declaration-on-Nutritionand-Noncommunicable-Diseases-in-the-Context-of-Health-2020-Eng.pdf?ua=1>.

2 World Healh Organization. Global strategy for the prevention and control of noncommunicable diseases. Report by the Director General [interaktyvus]. WHO Doc A53/14, 2000 [žiūreta 201501-08]. <http://apps.who.int/gb/archive/pdf_files/WHA53/ea14.pdf?ua=1>.

3 World Healh Organization. Vienna declaration on Nutrition and Noncommunicable diseases in the Context of Health 2020, op. cit.

4 Lietuvos Respublikos švietimo ir mokslo ministro 2010 m. kovo 23 d. ịsakymas Nr. 169/299 „Dèl vaikų ir moksleivių sveikatos apsaugos politikos strateginių gairių“. Valstybès žinios. 2000, Nr. 27-738. 
katos stiprinimo veikloje tarp vietos valdžios institucijų ir bendruomenių tampa aktualu analizuoti jų taikomas priemones ir nustatyti kliūtis, kurios kyla planuojant ir igyvendinant veiklą, skatinančią vaikų ir jaunimo sveiką mitybą bei fizini aktyvumą, kuri prisideda prie lètinių neinfekcinių ligų rizikos veiksnių mažinimo. Šio straipsnio tikslas - ịvertinti suinteresuotų grupių požiūrị ị veiksmingas vaikų ir jaunimo sveikatos stiprinimo politikos priemones fizinio aktyvumo bei sveikos mitybos srityje vietos bendruomenès lygmeniu.

\section{Tyrimo medžiaga ir metodai}

kokybinis tyrimas, taikant pusiau struktūrizuotą interviu, buvo atliktas 2013 metų liepos-rugsėjo mèn. igyvendinant sveikos mitybos ir fizinio aktyvumo skatinimo vietos bendruomenèse projektą (angl. Promoting healthy eating and physical activity in local communities, HEPCOM), kuriame dalyvauja 21 institucija iš 15 Europos šalių, tarp jų Lietuva ${ }^{5}$. Projektas vykdomas, igyvendinant Europos Komisijos antrosios Bendrijos veiksmų sveikatos srityje programos (2008-2013) antrojo uždavinio "Stiprinti sveikatą" veiklos, skirtos atkreipti dèmesį bei imtis veiksmų, susijusių su pagrindiniais lètinių neinfekcinių ligų veiksniais, tokiais kaip mityba ir fizinis aktyvumas. Vykdant tyrimą buvo taikyta projekto partnerio - Vokietijos Liuneburgo universiteto parengta ir su projekte dalyvaujančiomis šalimis suderinta tyrimo metodika ${ }^{6}$. Remiantis šioje metodikoje įvardintais kriterijais ir taikant dvipakopi atrankos metodą, tyrimui buvo pasirinktos Klaipedos miesto, Kauno ir Jurbarko rajonų savivaldybès. Kitu etapu kiekvienoje savivaldybeje pakviesti dalyvauti interviu suinteresuoti asmenys, atstovaujantys šioms grupèms: politikos formuotojai ir sprendimų prièmejjai, atsakingi už politikos formavimą ir strategijų kūrimą vaikų ir jaunimo sveikatos stiprinimo srityje (politikos lygmuo), administratoriai, planuojantys bei vertinantys vaikų ir jaunimo sveikatos stiprinimo veiklą (administravimo lygmuo) ir praktikai, atsakingi už sveikatos stiprinimo vaikų ir jaunimo sveikatos veiklos igyvendinimą vietos bendruomenèse (igyvendinimo lygmuo). Tokiu būdu tyrime dalyvavo dvylika suinteresuotų asmenų, užimančių vadovaujančias ir (ar) koordinuojančias pareigas iš minètų savivaldybių ir joms pavaldžių sveikatos bei švietimo institucijų. Tyrimas atliktas, vadovaujantis vienodais visose projekte dalyvaujančiose šalyse klausimais - politikų, administratorių ir praktikų taikomų ir reikalingų vaikų ir jaunimo sveikatos stiprinimo, išryškinant fizinị aktyvumą ir sveiką mitybą, veiklos planavimo ir igyvendinimo priemonių ir jų taikymo kliūčių įveikimo gairèmis, taip pat veiksniais, skatinančiais šių

European Commission. Project No 20121204 under EU Health Programme 2008-2013. Promoting healthy eating and physical activity in local communities (HEPCOM) [žiūrèta 2015-03-06]. $<$ http://ec.europa.eu/chafea/projects/database.html?prjno=20121204>.

6 Goelitz, D.; Paulus, P.; Vervoordeldonk, J., et. al. Mapping exercise, needs analysis and gap analysis for obesity prevention tools. Report HEPCOM needs analysis. Utrecht, 2014. 
priemonių naudojimą bei reikalingą paramą vystant sveikos stiprinimo veiklą vietos bendruomenèse. Šiame tyrime kaip priemonès įvardijami vadovai, metodikos ir metodinès priemonès, konceptualios gairès, modeliai, programos, kuriuos vietos bendruomenès taiko kuriant, planuojant, igyvendinant ir vertinant sveikatos stiprinimo veiklą, skirtą vaikams ir jaunimui fizinio aktyvumo bei sveikos mitybos skatinimo srityje. Vietos bendruomené apibrèžiama kaip grupé žmonių, kurie dalijasi bendromis vertybėmis ir normomis, yra veikiama tos pačios politinès situacijos ir aplinkos sąlygų ir kurios nariai gyvena geografiškai apibrèžtoje teritorijoje ${ }^{7}$. Šiame tyrime vietos bendruomene laikyta savivaldybè. Kokybinio tyrimo duomenų analizei taikytas turinio analizės metodas (angl. content), leidžiantis formuluoti išvadas remiantis analizuojamu tekstu ${ }^{8}$.

\section{Tyrimo rezultatai}

\section{Naudojamos priemonès ir jų taikymo kliūtys}

Tyrime dalyvavę politikai, administratoriai ir praktikai įvardijo priemones, kurias taiko planuojant ir igyvendinant vaikų ir jaunimo sveikatos stiprinimo veiklą (1 lentelè).

1 lentelè. Vaikų ir jaunimo sveikatos stiprinimo veiklos fizinio aktyvumo bei sveikos mitybos planavimo srityje taikomos ir reikalingos priemonès politikos, administravimo ir igyvendinimo lygmenimis

\begin{tabular}{|c|c|c|}
\hline LYGMUO & TAIKOMOS PRIEMONĖS & REIKALINGOS PRIEMONÉS \\
\hline $\begin{array}{c}\text { Politikos } \\
\text { lygmuo }\end{array}$ & $\begin{array}{l}\text { Strateginio planavimo metodika } \\
\text { „Strateginiame planavime: sudaroma } \\
\text { sutartis su Šilalès visuomenes sveikatos } \\
\text { biuru. Jie parengia ir pateikia veiklos } \\
\text { planą. Ji apima ir vaikus ir jaunima, mi- } \\
\text { tybos ir fizinio aktyvumo temas." } \\
\text { ES finansuojamos programos } \\
\text { „Vyriausybinés programos: vaisiu, pieno." } \\
\text { „Yra tokios pieno ir daržoviu programos. } \\
\text { Nežinau, kaip kituose miestuose, bet } \\
\text { mūsu mieste kažkaip sunkiai." } \\
\text { Stebèsenos programos } \\
\text { „Visa ko pradžia mums yra monitorin- } \\
\text { gas, kuri mes užsakome. Patvirtinama } \\
\text { savivaldybės taryboje monitoringo pro- } \\
\text { grama, monitoruojamos sritys."<...> Taip } \\
\text { pat naudojamés sveikatos rodikliais." }\end{array}$ & $\begin{array}{l}\text { Tarpsektorinis bendradarbiavimas for- } \\
\text { muojant sveikatos politiką } \\
\text { "Svarbios priemonés būtu, susijusios su } \\
\text { kitu politikų, ne tik sveikatos sektoriaus, } \\
\text { priimančiu sprendimus, nuostatų forma- } \\
\text { vimu." } \\
\text { Intervencijų vertinimo metodikos } \\
\text { "Reikalingos vertinimo metodikos. Kai ren- } \\
\text { gi strateginị plana, reikia pagrịsti, parodyti } \\
\text { vertinimo rezultatus, pateikti įrodymus." } \\
\text { "Absoliučiai būtu naudingos vertinimo } \\
\text { metodikos. Kaip ịvertinti intervencijas." }\end{array}$ \\
\hline
\end{tabular}

HEPCOM. Glossary [interaktyvus]. [žiūrèta 2015-03-06]. < http://files.hepcom.eu/uploads/ documents/glossary/en/hepcom_glossary.pdf >.

8 Bitinas, B.; Rupšienė L.; Žydžiūnaitè, V. Kokybiniu tyrimu metodologija. Klaipėda: S. Jokužio leidykla, 2008. 


\begin{tabular}{|c|c|c|}
\hline $\begin{array}{l}\text { Admini- } \\
\text { stravimo } \\
\text { lygmuo }\end{array}$ & $\begin{array}{l}\text { Strateginio planavimo metodika } \\
\text { „Tarsi yra strategija, ji taikyta konkre- } \\
\text { čioms grupems." „Yra bedu su strategiju } \\
\text { planavimu." } \\
\text { Tikslinės metodinès priemonès } \\
\text { „Naudojame planavimui jūsu parengta } \\
\text { sveikata stiprinančiu mokyklu metodinę } \\
\text { priemonę. Pagal ja nusistatome tikslus." } \\
\text { „Sveikata stiprinančiu mokyklu tinklo } \\
\text { mokyklos ja naudoja ịivertinimui." }\end{array}$ & 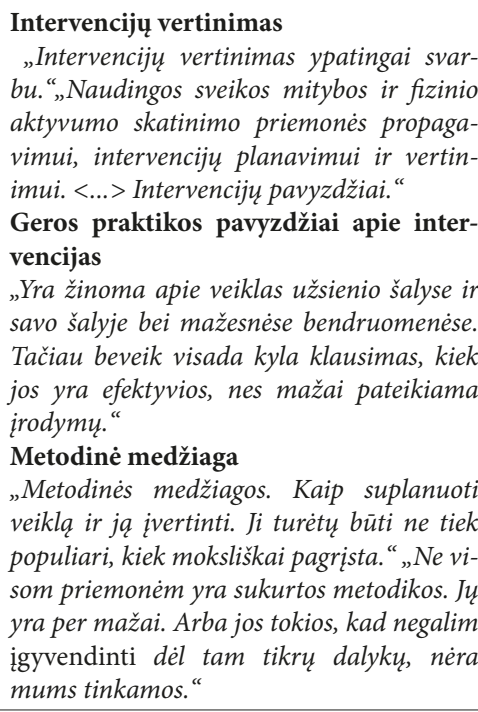 \\
\hline $\begin{array}{l}\text { Igyvendi- } \\
\text { nimo } \\
\text { lygmuo }\end{array}$ & 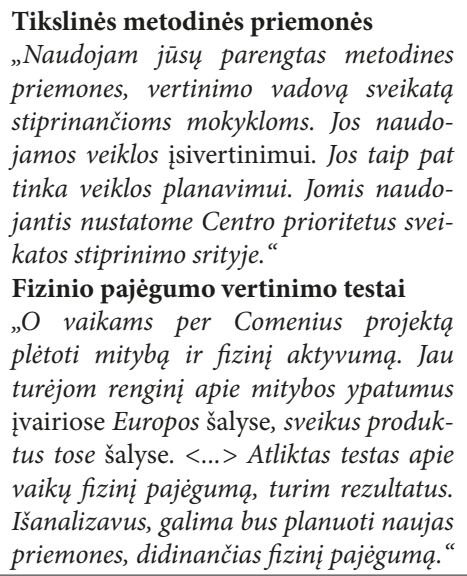 & $\begin{array}{l}\text { Metodinė medžiaga veiklos planavimui } \\
\text { „Tinkamos metodinés medžiagos pla- } \\
\text { navimui.“ } \\
\text { Intervencijų vertinimo priemonès } \\
\text { „Tada priemones kaip intervencijas vertinti. } \\
\text { Ne standartiness, bet kad žmones suprasty } \\
\text { kada, kaip taikyti.“ }\end{array}$ \\
\hline
\end{tabular}

Politikai ir administratoriai taiko politikos formavimo ir sprendimu prièmimo bei strateginio planavimo priemones (sveikatos stebèsenos programos, strateginio planavimo metodikos, tikslinès metodinès priemonės), taip pat koordinuoja savivaldybeje Europos Sąjungos vykdomos politikos priemones, pvz., vaisių ir daržovių vartojimą skatinančias programas ikimokyklinio ir bendrojo ugdymo mokyklose. Praktikai taiko sveikatos stiprinimo veiklos planavimo ir jos igyvendinimo priemones, tokias kaip tikslinès metodinès rekomendacijos, fizinio aktyvumo vertinimo testai. Politikai, administratoriai ir praktikai kaip vieną iš pagrindinių taikomų priemonių kliūtị nurodè žmogiškųjų išteklių svei- 
katos stiprinimo veiklos planavimui bei ịgyvendinimui stoką: „Fiziniai ištekliai. Vienas žmogus to negali padaryti“ (politikos lygmuo); „Neturejimas pakankamai žmogiškųjųišteklių-kompetentingųirnorinčiu planuoti irigyvendintiveiklas" (administravimo lygmuo); „Pirmiausiai potencialas darbuotojų, žmoniu iniciatyviu ir suprantančių, norinčiu ir žinančiu kaip daryti trūkumas" (igyvendinimo lygmuo). Politikai taikydami priemones susiduria su bendradarbiavimo stoka tarp savivaldybės departamentų: „Lyg ir yra savivaldybès bendruomené, bet kiekvienas sektorius dirba atskirai, pagal savo pareiginius aprašus. Trūksta bendradarbiavimo tarp sektorių", menku institucijų dalyvavimu ar įsitraukimu planuojant ir igyvendinant sveikatos programas vietos lygiu: „<...> jei daugiau teikty paraiškas. Dabar rašo pavieniai ir dažniausiai tie patys. Kad daugiau teiktu, reikia didesniu gebejimu, kaip rengti, kaip vertinti" bei nesusiformavusiu visuomenès požiūriu ì sveikatos išsaugojimą: „Dar vyrauja požiūris, kad sveikata - mediku reikalas. Tèvu požiūris nesusiformavęs. "Neigiamą požiūrị ị sveikatos stiprinimą kaip taikomų priemonių igyvendinimo kliūtị pažymèjo ir praktikai: „Pagrindine kliütis kai kuriu mokyklų bendruomeniu pasyvus požiūris ị sveikatos stiprinimo veikla ir šiu metodiniu priemoniu naudojima." Administratoriai akcentavo finansavimo kliūtị, kylančią planuojant vaikų ir jaunimo sveikatos stiprinimo veiklą vietos bendruomeneje: „Kita problema, žinoma, finansavimas.“

Tyrime buvo siekiama išsiaiškinti pagrindinius veiksnius, skatinančius politikus, administratorius ir praktikus taikyti priemones. Politikų požiūriu, priemonių taikymą skatina tokie veiksniai kaip žiniasklaida, formuojanti visuomenès požiūrị: „Ir taip pat problema spauda. Ji nerašo apie tai, kas gerai buvo, apie teigiamus dalykus"; "Ji taip suformuoja neigiama visuomenés nuomonę", finansinių lèšų skyrimas atsižvelgiant ì bendruomenès poreikius: „Savivaldybeje yra sveikatos programu rémimo fondas. Per ji galima bütu finansuoti tikslines programas"; „Tas lèšu skyrimas pačioms bendruomenems, kai jos pačios nusprendžia, ko joms reikia, tai tikrai rimta priemoné; taip pat infrastruktūros fiziniam aktyvumui kūrimas: „Kai sudaryta gera infrastruktūra užsiimti fizine veikla, turi nori nenori ja naudojiesi. Pavyzdžiui, Klaipédos mieste yra parengta 2012-2013 m. klaipédiečiu judejimo schema, sudarytas virtualus fizinio aktyvumo žemèlapis, kur yra didelis užsiemimu pasirinkimas, pažymèti dviračiu takai ir visi užsiemmimai nemokami gyventojams." Administratoriai ir praktikai pažymejjo, kad metodinių priemonių prieinamumas tiesiogiai susijęs su jų taikymu: „Vien turèti priemoniu nepakanka. Reikia, kad jos bütu išverstos i nacionalinę kalbą. Jei ir parengtos nacionaline kalba, reikia, kad jos bütu pristatytos ir tie, kurie naudos, bütu apmokyti“ (administravimo lygmuo); „Mums reikalinga iš šalies parengtu specialistu metodine pagalba" (igyvendinimo lygmuo). Administratorių požiūriu, priemonių taikymas priklauso nuo žmogiškųjų išteklių: "Turéjimas pakankamai žmogiškuju ištekliü“; tikslingo veiklos planavimo: „Kadangi mūsu veikla vyksta programiniu ir projektiniu būdu <...> ir 
bendradarbiavimo su partneriais: „Manau, $k a$ mes pasiekèm, $k a$ darom dabar, tai labai gražūs bendradarbiavimo ryšiai." Praktikai pažymèjo, kad priemonès taikomos igyvendinant projektus: „O mokiniams šiemet darèm su fiziniu aktyvumu ir sveika mityba susijusius projektus“, taip pat integruojant juos į ugdymo ir sveikatos planus.

\section{Reikalingos priemonès ir jų diegimo kliūtys}

Mitybos ir fizinio aktyvumo intervencijas ir jų vertinimo metodikas kaip reikalingas priemones ívardijo politikai, administratoriai ir praktikai. Politikai kaip pagrindines šių reikalingų priemonių diegimo kliūtis nurodè intervencijų vertinimo metodikų stoką: „Dabar metodikas rengia daug kas. <...> Metodikas turi ruošti moksliniu lygmeniu“ ir ribotą informacijos prieinamumą: „Lietuvoje nèra tokios duomenu bazés, kur galetum surasti reikiamos priemonès", o administratoriai - finansinių lèšų ir žmogiškųjų išteklių, vertinančių intervencijas, trūkumą: „Finansinių ir žmogiškuju ištekliu trūkumas, matuojant veiklas“; „Kita problema, žinoma, finansavimas." Politiko požiūriu, reikalingas tarpsektorinis bendradarbiavimas formuojant ir igyvendinant sveikatos politiką: „Svarbios priemones būtu susijusios su kitu politiku, ne tik sveikatos sektoriaus, priimančiu sprendimus, nuostatu formavimu“, jo nuomone, aiškios sveikatos politikos vizijos turẻjimas leistų siekti keliamų tikslų, „Konkretizuoti politiką. Ja labiau apsibrëžti konkrečiam laikotarpiui. Dabar daug problemų. Jas prioretizuoti.“ Nacionalinès politikos ịgyvendinimą savivaldos lygiu pabrèžè kitas politikas: „Aš kalbu apie nacionalines politikos igyvendinima savivaldybeje. Savivaldybe neturi išradinèti, o mokèti igyvendinti nacionaline politika galima igyvendinti, jei ją kuria kompetentingi žmonès." Norint priemones taikyti praktikoje, administratoriaus nuomone, reikalingi metodinių priemonių pristatymų organizavimas: „Pagerintu šiu priemoniu pristatymas. Tarkim, išeina nauja priemone ir ji pristatoma mums kaip specialistams“, o praktikas pažymejjo mokymų ir konsultavimo poreikį: „Mokymai, konsultacijos, ką planuoti, kaip planuoti intervencijas ir kaip jas vertinti. Reikètų ir pagalbos vertinant veiklas, apmokant metodikų taikymo mokytojus." Kitas praktikas išskyrè vieną iš priemonių diegimo kliūtị: „Galbūt kai kurios priemonès netiktu visoms mokykloms. Neturètu galimybiu jas taikyti, pavyzdžiui, neturi tam inventoriaus, kitaip išdèstytos pamokos (atskiros ar integruotos). Priklauso nuo bendruomenes. Ji gali kreipti demesį daugiau i kita sriti, pvz., narkotiku prevencija - ne fizinį aktyvuma. Kaip susistato prioritetus." 


\section{Parama plètojant sveikatos stiprinimo veiklą vietos bendruomenejje}

Politikai, administratoriai ir praktikai linkę ịgyvendinti veiklas, skatinančias fizinį aktyvumą ir sveiką mitybą vietos bendruomenèse, tačiau jų igyvendinimui trūksta paramos šalies ir vietos lygiu (2 lentelè).

2 lentelè. Parama reikalinga plètojant vaikų ir jaunimo sveikatos stiprinimo veiklą fizinio aktyvumo bei sveikos mitybos srityje vietos bendruomenèse politikos, administravimo ir igyvendinimo lygmenimis

\begin{tabular}{|c|c|c|c|}
\hline PARAMA & POLITIKOS LYGMUO & $\begin{array}{l}\text { ADMINISTRAVIMO } \\
\text { LYGMUO }\end{array}$ & $\begin{array}{l}\text { IGYVENDINIMO } \\
\text { LYGMUO }\end{array}$ \\
\hline $\begin{array}{l}\text { Politika ir } \\
\text { aiškūs tik- } \\
\quad \text { slai }\end{array}$ & 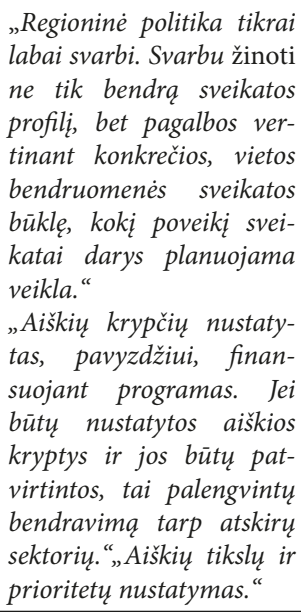 & $\begin{array}{l}\text { "Jei būtu formuojama } \\
\text { regionine politika. Būtu } \\
\text { aiškūs tikslai. Tada būtú } \\
\text { lengviau planuojamos } \\
\text { praktinès veiklos." } \\
\text { "100 proc. būtina } \\
\text { regioninè politika, vie- } \\
\text { tos sveikatos strategija, } \\
\text { būtinai reikalingi aiškūs } \\
\text { nusistatyti tikslai. Tü } \\
\text { problemu daug, todèl } \\
\text { aiškūs nusistatyti tikslai } \\
\text { metams visuose lygi- } \\
\text { uose." } \\
\text { "Palaikymas turètu būti } \\
\text { ne tik vietos, bet ir na- } \\
\text { cionaliniulygmeniu." }\end{array}$ & $\begin{array}{l}\text { „Svarbu regioninèj politikos } \\
\text { sudèlioti akcentus. Tada jie } \\
\text { perkeliami í mokyklu metin- } \\
\text { ius veiklos planus." }\end{array}$ \\
\hline $\begin{array}{l}\text { Bendradar- } \\
\text { biavimas } \\
\text { su išorès } \\
\text { partneriais } \\
\text { ir (ar) kole- } \\
\text { gomis }\end{array}$ & $\begin{array}{l}\text { „O pagal mane, ju (biuru) } \\
\text { stiprioji pusè turètu büti } \\
\text { ne paslaugu teikimas, o } \\
\text { jie turi būti komandoj } \\
\text { su savivaldybès gydy- } \\
\text { toju. <...>Mes turètumèm } \\
\text { strate-guoti rajono sveika- } \\
\text { tos dalykus. Savivaldybej } \\
\text { yra ìvairūs skyriai, tai ir } \\
\text { žemès ūkio, socialines, } \\
\text { švietimo, urbanistikos, } \\
\text { aplinkos. Visi skyriai gali } \\
\text { kažka nuveikti sveikatos } \\
\text { gerinimo srityje." }\end{array}$ & $\begin{array}{l}\text { "Bendradabiavimas } \\
\text { visais lygiais labai svar- } \\
\text { bus." } \\
\text { "Svarbus bendradarbia- } \\
\text { vimas su universitetais, } \\
\text { vietos valdžia." }\end{array}$ & $\begin{array}{l}\text { „Prašau, kad būtu sudaro- } \\
\text { mas vaiku, turinčiu sveika- } \\
\text { tos problem, sąrašas, kad } \\
\text { žinočiau, kokios problemos. } \\
\text { Kad sveikatos specialistè } \\
\text { informuotu apie apžiūras, } \\
\text { bendra vaizda, kokias prob- } \\
\text { lemas turim, ir aptarti, kaip } \\
\text { tuos vaikus sveikatinti, tada } \\
\text { mokymai ta tematika orga- } \\
\text { nizuojami mokytojams, kaip } \\
\text { su tais vaikais elgtis." } \\
\text { "Bendradarbiavimas tarp } \\
\text { mokyklu svarbus. Tèvu } \\
\text { ittraukimas, prioritetiniu } \\
\text { sveikatos tikslu nusistaty- } \\
\text { mas.<...> Kad būtuirtarps- } \\
\text { ektorinis bendra-darbiavi- } \\
\text { mas." }\end{array}$ \\
\hline
\end{tabular}




\begin{tabular}{|c|c|c|c|}
\hline $\begin{array}{l}\text { Finansavi- } \\
\text { mas }\end{array}$ & & $\begin{array}{l}\text { "Svarbi ir finansine } \\
\text { parama.“ „Viskas atsire- } \\
\text { mia i finansus." }\end{array}$ & $\begin{array}{l}\text { "<..> Ir finansai, kad būtu } \\
\text { daugiau sąlygu mokykloje ir } \\
\text { prie mokyklos užsiimti fizine } \\
\text { veikla." }\end{array}$ \\
\hline Mokymai & $\begin{array}{l}\text { "Mokymai ivairiose } \\
\text { srityse: lyderystès, ben- } \\
\text { dravimo, projektu ren- } \\
\text { gime, ju vertinime. Viskas } \\
\text { susiveda i žmogiškuosius } \\
\text { išteklius, ju gebèjimus." } \\
\text { "Kvalifikuoti darbuotojai } \\
\text { turi daugiau idèju ir jas } \\
\text { lengviau igyvendina." }\end{array}$ & & $\begin{array}{l}\text { „Darbuotoju kvalifikacijos } \\
\text { kèlimas nuolatinis reika- } \\
\text { lingas. Daug ideju suteikia } \\
\text { dalyvavimas tarptautiniuose } \\
\text { projektuose." }\end{array}$ \\
\hline $\begin{array}{l}\text { Infor- } \\
\text { macija apie } \\
\text { geriausią } \\
\text { praktiką }\end{array}$ & $\begin{array}{l}\text { „Geros praktikos sklaida. } \\
<\ldots . .>\text {. Žinojimas apie ịvai- } \\
\text { rias intervencijas, i̇vairias } \\
\text { praktikas ir ju kaina." } \\
\text { "Žinojimas apie gera } \\
\text { praktikg dar labiau padé- } \\
\text { tų. Keistis patirtimi." }\end{array}$ & $\begin{array}{l}\text { „Taip pat žinojimas apie } \\
\text { pasiteisinusias program- } \\
\text { as su i̇rodymais, kad jos } \\
\text { veiksmingos.” } \\
\text { "Patirties sklaida, ypač } \\
\text { kuri pasiteisimo. } \\
<\ldots>\text { Aš apsistočiau ties } \\
\text { pažangia ir } \\
\text { gera praktika. Kad } \\
\text { turètum geriausia, turi } \\
\text { büti visu lygmenu para- } \\
\text { ma." }\end{array}$ & \\
\hline $\begin{array}{l}\text { Vertinimo } \\
\text { ịrankiai }\end{array}$ & $\begin{array}{l}\text { „Tai pat vertinimo } \\
\text { irankiai, kuriu labai } \\
\text { reikia. <...> Reikètu pro- } \\
\text { gramas vertinti ir šiuo } \\
\text { (sveikatos) atžvilgiu. ",Mes } \\
\text { dažniausiai vertinam } \\
\text { kiekybinius rodiklius. Nera } \\
\text { tokio vertinimo tradiciju." } \\
\text { „Sunku vertinti. Reikia } \\
\text { gero žinojimo kaip ver- } \\
\text { tinti, jo trūksta, gebéjimo, } \\
\text { kokie vertinimo kriterijai.“ } \\
\text { „Su vertinimu iš ties yra } \\
\text { problemu. Viena, mes ne- } \\
\text { turim metodiku, kita, mes } \\
\text { nemokam daryti. " }\end{array}$ & & \\
\hline
\end{tabular}

Politikai, administratoriai ir praktikai kaip svarbią paramą veiklos strateginio planavimo procese ịvardino regioninès politikos formavimą: „Regionine politika tikrai labai svarbi. Svarbu žinoti ne tik bendra sveikatos profili, bet pagalbos vertinant konkrečios vietos bendruomenès sveikatos būkle, koki poveiki sveikatai darys planuojama veikla“ (politikos lygmuo). „Jei bütu formuojama regioniné 
politika. Būtu aiškūs tikslai. Tada būtų lengviau planuojamos praktinès veiklos" (administravimo lygmuo). „100 proc. bütina regionine politika, vietos sveikatos strategija, bütinai reikalingi aiškūs nusistatyti tikslai. Tu problemu daug, todèl aiškūs nusistatyti tikslai metams visuose lygiuose" (administravimo lygmuo). „Svarbu regioninejj politikoj sudèlioti akcentus. Tada jie perkeliami i mokyklu metinius veiklos planus" (igyvendinimo lygmuo). Politikai pabrèžè aiškių tikslų ir prioritetų nustatymo poreikị: „Sakyčiau, pirmiausia turètų büti aiški valstybès politika. Aiškūs prioritetai ir tikslai“; „Aiškiu krypčiu nustatymas, pvz., finansuojant programas. Jei būtų nustatytos aiškios kryptys ir jos būtu patvirtintos, tai palengvintu bendravima tarp atskiru sektoriu“"; „Aiškiu tikslu ir prioritetu nustatymas" ir savivaldos lygio institucijų bendradarbiavimo reikšmę, Łgyvendinant sveikatos stiprinimo veiklas: „Mes turètumèm strateguoti rajono sveikatos dalykus. Savivaldybèj yra ịvairūs skyriai, tai ir žemès ūkio, socialinès, švietimo, urbanistikos, aplinkos. Visi skyriai gali kažką nuveikti sveikatos gerinimo srityje." Tarpinstitucinị bendradarbiavimą kaip reikalingą paramą ịvardijo administratoriai: „Bendradabiavimas visais lygiais labai svarbus“, „Svarbus bendradarbiavimas su universitetais, vietos valdžia“, o praktikai pabrèžè bendradarbiavimą tarp mokyklų: „Bendradarbiavimas tarp mokyklu svarbus. Tẻvu įtraukimas, prioritetiniu sveikatos tikslu nusistatymas“ ir kolegu „Kad sveikatos specialiste informuotu apie apžiūras, bendra vaizda, kokias problemas turim, ir aptarti kaip tuos vaikus sveikatinti, tada mokymai ta tematika organizuojami mokytojams, kaip su tais vaikais elgtis. "Sveikatos stiprinimo veiklu igyvendinimui reikalingi specialistu mokymai: „Darbuotoju kvalifikacijos kèlimas pastovus reikalingas. Daug ideju suteikia dalyvavimas tarptautiniuose projektuose" (igyvendinimo lygmuo); „Mokymai įvairiose srityse: lyderystès, bendravimo, projektu rengime, ju vertinime. Viskas susiveda į žmogiškuosius išteklius, ju gebejjimus" (politikos lygmuo). Politikai ir administratoriai pažymejjo, kad jiems reikalingas informacijos apie gerąją praktiką prieinamumas: „Geros praktikos sklaida. <...> Žinojimas apie ivairias intervencijas, ịvairias praktikas ir jų kaina“; „Žinojimas apie gerą praktiką dar labiau padetų. Keistis patirtimi.“ (politikos lygmuo); „Taip pat žinojimas apie pasiteisinusias programas su įrodymais, kad jos veiksmingos" (administravimo lygmuo); „Patirties sklaida, ypač kuri pasiteisino. <...> Ašapsistočiau ties pažangia ir gera praktika. Kad turèti geriausią, turi būti visu lygmenu parama" (administravimo lygmuo). Be to, politikai nurode ir intervencijų vertinimo įrankių reikalingumą ir jų vertinimo problemas: „Tai pat vertinimo įrankiai, kuriu labai reikia. <...> Reikètu programas vertinti ir šiuo (sveikatos) atžvilgiu“; „Nèra tokio vertinimo tradiciju“; „Sunku vertinti. Reikia gero žinojimo, kaip vertinti, jo trūksta, gebejjimo, kokie vertinimo kriterijai“; „Su vertinimu išties yra problemu. Viena, mes neturim metodiku, kita, mes nemokam daryti." 


\section{Rezultatų aptarimas}

europos šalyse atlikti tyrimai, taikant tą pačią tyrimo metodologiją kaip ir Lietuvoje, rodo taikomų ir reikalingų sveikatos stiprinimo priemonių vaikų ir jaunimo fizinio aktyvumo ir sveikos mitybos srityje įvairovę, kurią lemia konkrečiųvietos bendruomenių poreikiai ${ }^{9}$. Remiantis sveikatosveiklos ciklo modeliu šias priemones galima priskirti politikos ir sprendimų priemimo, strateginio planavimo, veiklos planavimo, igyvendinimo ir vertinimo priemonių grupėms ${ }^{10}$. Pažymėtina, kad šiu priemonių cikliškas ar tęstinis taikymas leidžia kryptingai formuoti ir igyvendinti sveikatos stiprinimo veiklą vietos bendruomenèse. Atliktas vienas pirmųjų tyrimų, analizuojančių vietos valdžios ir bendruomenių sveikatos stiprinimo veiklos planavimo ir igyvendinimo priemones, išryškino jų taikymo aktualijas ir problemines sveikatos stiprinimo politikos igyvendimo vietos bendruomenèse sritis. Vietos politikai ir administratoriai planuodami sveikatos stiprinimo veiklą taiko strategini planavimą, kuris leidžia apibrèžtu laikotarpiu nustatyti veiklos prioritetus ir numatyti jos igyvendinimo priemones. Tačiau jau sveikatos stiprinimo veiklos planavimo procesuose vietos politikai susiduria su bendradarbiavimo su kitų savivaldybès departamentų atstovais trūkumu, taip pat menku institucijų dalyvavimu planuojant ir ịgyvendinant sveikatos programas. Autoriai, analizavę Pasaulio sveikatos organizacijos Europos regiono šalių strateginius dokumentus, pažymi tarpdisciplininio bendradarbiavimo stoką formuojant ir igyvendinant politiką fizinio aktyvumo skatinimo srityje $^{11}$. Atlikto tyrimo duomenys leidžia kelti prielaidą, jog nors suinteresuotos grupès (tokios kaip savivaldybès ir bendruomenių atstovai) pripažįstami sveikatos politikos dalyviais, tačiau jie deramai neitraukiami ił sveikatos stiprinimo politikos formavimo procesus. Vietos valdžios institucijos Olandijoje, kaip ir Lietuvoje, formuoja sveikatos stiprinimo politiką bendruomeneje ir užima pagrindinę poziciją bendradarbiaujant su suinteresuotais atstovais, tačiau politinès lyderystès, tarpsektorinès politikos ir kryptingų veiksmų vystymo kliūtys trukdo išvystyti sveikatos stiprinimo modelị bendruomenejje ${ }^{12 .}$

Nacionalinė sveikatos taryba, Lietuvos Respublikos Seimui atskaitinga sveikatos politikos koordinavimo institucija, išreiškusi susirūpinimą moderniosios visuomenès sveikatos politikos ịgyvendinimu savivaldybių lygiu, ragina įsitraukti kitų sektorių atstovus ị sveikatos problemų sprendimą, igyvendinant „svei-

Goelitz, D.; Paulus, P.; Vervoordeldonk, J., et. al., supra note 6.

Ibid.

11 Daugbjerg, S. B.; Kahlmeier, S.; Racioppi F., et al. Promotion of physial activity in the European region: content analysis of 27 national policy documents. Journal of Physical Activity and Health. 2009, 6: 805-817.

12 Hoeijmakers, M.; De Leeuw, E.; De Vries, N. K. Local health policy development processes in the Netherlands: an expanded toolbox for health promotion. Health Promotion International. 2007, 22 (2): 112-21. 
kata visose politikose" principą $^{13 .}$ Šio principo iggyvendinimą skatina Pasaulio sveikatos organizacija ${ }^{14,15}$, Europos Sąjungos institucijos ${ }^{16,17}$ ir jis pabrěžiamas tokiuose šalies strateginiuose dokumentuose kaip 2014-2010 m. nacionalinès pažangos programos horizontalusis prioritetas "Sveikata visiems ${ }^{\text {"118 }}$ ir jos tarpinstitucinis veiklos planas ${ }^{19}$, Lietuvos sveikatos 2014-2025 metų programa ${ }^{20}$, tačiau bendra visų sektorių veikla sprendžiant sveikatos problemas ir tarpinstitucinis bendradarbiavimas išlieka iššūkiu. Tarpinstitucinio bendradarbiavimo Europos šalyse analizė rodo, kad jis geriau išplètotas tose šalyse, kuriose strateginio planavimo sistema labiau centralizuota21. Šioje srityje lyderèmis laikomos Suomija, Jungtinè Karalystė, turinčios didelę ir tarpinstitucinių dokumentų rengimo patirtiti 22 .

Atliktame tyrime išryškejjo, kad vietos politikams, igyvendinantiems nacionalinę sveikatos politiką vietos bendruomenėse, kyla ir prioritetų nustatymo problema. Vietos politikai Lietuvos Respublikos Vyriausybès ir kitų vykdomosios valdžios institucijų aiškių politikos tikslų ir prioritetų nustatymą šalies lygiu laiko svarbia parama jų veiklos planavimui, lèšų skyrimui visuomenės sveikatos problemų sprendimui ir priemonių igyvendinimui. Remiantis tyrimo duomenimis, administratoriai planuodami sveikatinimo veiklą vietos

13 Nacionalinès sveikatos tarybos 2013 m. lapkričio 26 d. nutarimas Nr. N-5 „Dèl modernios visuomenès sveikatos sampratos ugdymo" [žiūrèta 2015-01-08]. <www3.lrs.lt/docs2/VEJDKCWU. DOC>.

14 World Health Organization. Health 2020: a European policy framework supporting action across government and society for health and well-being [interaktyvus]. WHO EUR/RC62/9, 2012 [žiūrèta 2015-01-08].< http://www.euro.who.int/_data/assets/pdf_file/0009/169803/RC62wd09Eng.pdf?ua $=1>$.

15 World Health Organization. Adelaide statement on health in all policies: moving towards a shared governance for health and well-being [interaktyvus]. 13-15 April 2010, Adelaide [žiūrèta 201503-06]. < http://www.who.int/social_determinants/publications/isa/hiap_statement_who_sa_final.pdf?ua $=1>$.

16 Commission White paper of 23 October 2007 Together for health: a strategic approach for the EU 2008-2013. COM/2007/630.

17 Council of European Union. Council Conclusions of 30 November 2006 on Health in All Policies (HiAP). 16167/06.

18 Lietuvos Respublikos Vyriausybès 2012 m. lapkričio 28 d. nutarimas Nr. 1482 „2014-2010 metu nacionalinès pažangos programos patvirtinimo“. Valstybés žinios. 2012, Nr. 144-7430.

19 Lietuvos Respublikos Vyriausybès 2014 m. kovo 26 d. nutarimas Nr. 293 „Dèl 2014-2020 m. nacionalinès pažangos programos horizontaliojo prioriteto "Sveikata visiems" tarpinstitucinio veiklos plano patvirtinimo“. Teises aktu registras. 2014, Nr. 2014-04113.-

20 Lietuvos Respublikos Seimo 2014 m. birželio 26 d. nutarimas Nr. XII-964 „Dèl Lietuvos sveikatos 2014-2025 metų programos patvirtinimo“. Teisés aktų registras. 2014, Nr. 2014-9403.

21 Viešosios politikos ir vadybos institutas. Tarpinstitucinio bendradarbiavimo analizès atlikimo, analogiškos patirties ES šalyse ir esamos teisinès bazés Lietuvoje įvertinimo. Galutinè ataskaita [interaktyvus]. Vilnius, 2012. [žiūrèta 2015-01-08]. <http://www.esparama.lt/es_parama_pletra/ failai/ESFproduktai/2012_tarpinstitucinio_bendradarbiavimo_analize.pdf $>$.

Ibid. 
bendruomenèse susiduria su ribotu finansavimu. Kiti tyrejjai pažymi finansinių ištekliu stoką kaip vieną iš visuomenès sveikatinimo per sportą politikos igyvendinimo kliūtị Lietuvoje ${ }^{23 .}$. Finansiniai ištekliai, skiriami sveikatos stiprinimo veiklai igyvendinti, išlieka aktualiu klausimu ir kitų šalių vietos valdžioms, pavyzdžiui, Švedijoje, kurioje sveikatos prioritetas integruotas ị kitų sektorių politikas $^{24}$. Šioje šalyje vietos valdžios (savivaldybès) aiškūs sveikatos stiprinimo tikslai ir veiksmai, atsižvelgiant $\mathfrak{i}$ bendruomenès poreikius, tarpsektorinis bendradarbiavimas ir aktyvus vietos bendruomenès lyderių ịsitraukimas leidžia užtikrinti nuoseklų ir ilgalaikị sveikatos stiprinimą vietos lygiu ${ }^{25}$. Lietuvoje, kaip ir kitose šalyse, vis aktulesnis tampa ịrodymais grịstos politikos formavimas, kuris užtikrina efektyvų finansinių išteklių naudojimą ${ }^{26 .}$

Remiantis atlikto tyrimo duomenimis, sveikatinimo stiprinimo veiklos igyvendinimui benduomenèse reikalingos intervencijos ir jų vertinimo įrankiai, taip pat gerosios praktikos pavyzdžiai. Vietos politikai, formuojantys politiką, susiduria su informacijos apie veiksmingų intervencijų taikymą prieinamumo problema, be to, jie nurodè intervencijų vertinimo metodikų stoką. Praktikai igyvendindami sveikatos stiprinimo veiklą taiko tikslines metodines priemones, tačiau jiems trūksta intervencijų planavimo mokymų. Kita tyrime išryškejjusi problema - žmogiškųjų išteklių, vertinančių taikomas intervencijas, stoka. Tyrimo duomenys leidžia teigti, kad, veiksmingų intervencijų ir jų vertinimo priemonių stoka riboja sveikatos stiprinimo veiklos planavimą, taip pat pagrịstų sprendimų prièmimą dèl jų taikymo, siekiant bendruomenių sveikatos efekto turimais ribotais ištekliais. Lietuvoje, kaip ir kitose šalyse, diegiamų ir taikomų intervencijų visuomenès sveikatos srityje vertinimas tapo aktualia sveikatos politikos igyvendinimo dalimi ${ }^{27 .}$

\section{Išvados}

Vietos politikai ir administratoriai planuodami vaikų ir jaunimo sveikatos stiprinimo veiklą fizinio aktyvumo ir sveikos mitybos srityje dažniausiai taiko politikos ir sprendimų priemimo bei strateginio planavimo priemones, o praktikai - veiklos planavimo ir jos igyvendinimo priemones. Pagrindinès kliūtys,

23 Čingienė, V.; Lakienè, S. Lietuvos visuomenès sveikatinimo per sportą politikos igyvendinimo aktualijos „Europos Sąungos fizinio aktyvumų gairių“ kontekste. Sveikatos politika ir valdymas. 2014, 1(6): 116-124.

24 Jansson, E. V; Tillgren, P. E. Health promotion at local level: a case study of content, organization and development in four Swedish municipalities. BMC Public Health. 2010, 10: 455.

25 Jansson, E. V.; Tillgren, P. E., supra note 23.

26 Mikulskienė, B. Moksliniais tyrimais ir ịrodymais grịsta viešoji politika. Viešasis administravimas. 2011, 2(30): 36-43.

27 Jankauskiene, D.; Petronytè, G. A model for HTA priority setting: experience in Lithuania. International Journal of Technology Assessment in Health Care. 2013, 29 (4): 450-455. 
kylančios taikant šias priemones: tarpsektorinio bendradarbiavimo stoka, finansinių ir žmogiškųjų išteklių trūkumas bei pasyvus vietos bendruomenių požiūris į fizinio aktyvumo ir sveikos mitybos skatinimo veiklą.

Planuojant ir igyvendinant vaikų ir jaunimo sveikatos stiprinimo veiklą reikalingos intervencijų vertinimo priemonès ir jas taikantys žmogiškieji ištekliai, taip pat šioje srityje vietos bendruomenèse organizuojami pristatymai ir mokymai.

Vaikų ir jaunimo sveikatos stiprinimo veiklos vystymui būtinos šios prielaidos: kryptinga šalies sveikatos politikos strategija ir nustatyti prioritetai, tarpinstitucinis bendradarbiavimas, tarpsektorinè veikla, prieinamos informacijos apie geros praktikos intervencijas ir jų vertimo įrankius, taip pat žmogiškieji, finansiniai bei informaciniai ištekliai.

\section{Padèka}

Straipsnio autorès dèkoja Klaipėdos miesto, Kauno ir Jurbarko rajonų savivaldybių ir joms pavaldžių institucijų vaikų ir jaunimo sveikatos stiprinimo veiklos planavimu ir igyvendinimu suinteresuotiems asmenims: Klaipédos miesto savivaldybės Socialinių reikalų departamento sveikatos apsaugos skyriaus, Ugdymo ir kultūros departamento sporto ir kūno kultūros skyriaus; Savivaldybès visuomenès sveikatos biuro vadovams, Kauno rajono savivaldybės gydytojui, Švietimo centro direktorei, Šlienavos pagrindinès mokyklos sveikatos stiprinimo veiklos koordinatorei; Jurbarko rajono savivaldybės gydytojui, Jaunimo reikalų koordinatorei ir Seredžiaus pagrindinès mokyklos direktoriui už išsakytas mintis bei įžvalgas.

\section{Literatūra}

1. Bitinas, B.; Rupšienè, L.; Žydžiūnaitè, V. Kokybiniu tyrimu metodologija. Klaipėda: S. Jokužio leidykla, 2008.

2. Commission White paper of 23 October 2007 Together for health: a strategic approach for the EU 2008-2013. COM/2007/630.

3. Council of European Union. Council Conclusions of 30 November 2006 on Health in All Policies (HiAP). 16167/06.

4. Čingienè, V.; Lakienė, S. Lietuvos visuomenès sveikatinimo per sportą politikos igyvendinimo aktualijos „Europos Sąjungos fizinio aktyvumų gairių“ kontekste. Sveikatos politika ir valdymas. 2014, 1(6): 116-124.

5. Daugbjerg, S. B.; Kahlmeier, S.; Racioppi F., et al. Promotion of physial activity in the European region: content analysis of 27 national policy documents. Journal of Physical Activity and Health. 2009, 6: 805-817.

6. European Commission. Project No 20121204 under EU Health Programme 2008-2013. Promoting healthy eating and physical activity in local communities (HEPCOM) [žiūrèta 2015-03-06]. <http://ec.europa.eu/chafea/projects/database. html?prjno $=20121204>$. 
7. Goelitz, D.; Paulus, P.; Vervoordeldonk, J., et. al. Mapping exercise, needs analysis and gap analysis for obesity prevention tools. Report HEPCOM needs analysis. Utrecht, 2014.

8. HEPCOM Glossary [interaktyvus]. [žiūrèta 2015-03-06]. <http://files.hepcom.eu/ uploads/documents/glossary/en/hepcom_glossary.pdf $>$.

9. Hoeijmakers, M.; De Leeuw, E.; De Vries, N. K. Local health policy development processes in the Netherlands: an expanded toolbox for health promotion. Health Promotion International. 2007, 22 (2): 112-21.

10. Jankauskienè, D.; Petronyte், G. A model for HTA priority setting: experience in Lithuania. International Journal of Technology Assessment in Health Care. 2013, 29 (4): 450-455.

11. Jansson, E. V.; Tillgren, P. E. Health promotion at local level: a case study of content, organization and development in four Swedish municipalities. BMC Public Health. 2010, 10: 455.

12. Lietuvos Respublikos Seimo 2014 m. birželio 26 d. nutarimas Nr. XII-964 „Dèl Lietuvos sveikatos 2014-2025 metų programos patvirtinimo“. Teisés aktu registras. 2014, Nr. 2014-9403.

13. Lietuvos Respublikos švietimo ir mokslo ministro 2010 m. kovo 23 d. Nr. 169/299 „Dèl vaikų ir moksleivių sveikatos apsaugos politikos strateginių gairių“. Valstybès žinios. 2000, Nr. 27-738.

14. Lietuvos Respublikos Vyriausybès 2012 m. lapkričio 28 d. nutarimas Nr. 1482 „20142010 metų nacionalinès pažangos programos patvirtinimo“. Valstybės žinios. 2012, Nr. 144-7430.

15. Lietuvos Respublikos Vyriausybès 2014 m. kovo 26 d. nutarimas Nr. 293 „Dèl 2014$2020 \mathrm{~m}$. nacionalinès pažangos programos horizontaliojo prioriteto „Sveikata visiems“ tarpinstitucinio veiklos plano patvirtinimo“. Teisés aktų registras. 2014, Nr. 2014-04113.

16. Mikulskienè, B. Moksliniais tyrimais ir ịrodymais grịsta viešoji politika. Viešasis administravimas. 2011, 2(30): 36-43.

17. Nacionalinès sveikatos tarybos 2013 m. lapkričio 26 d. nutarimas Nr. N-5 „Dèl modernios visuomenès sveikatos sampratos ugdymo" [žiūrèta 2015-01-08]. <www3. lrs.lt/docs2/VEJDKCWU.DOC $>$.

18. Viešosios politikos ir vadybos institutas. Tarpinstitucinio bendradarbiavimo analizès atlikimo, analogiškos patirties ES šalyse ir esamos teisinès bazès Lietuvoje įvertinimo. Galutinė ataskaita [interaktyvus]. Vilnius, 2012 [žiūrèta 2015-01-08]. <http:// www.esparama.lt/es_parama_pletra/failai/ESFproduktai/2012_tarpinstitucinio_ bendradarbiavimo_analize.pdf $>$.

19. World Healh Organization. Global strategy for the prevention and control of noncommunicable diseases. Report by the Director General [interaktyvus]. WHO Doc A53/14, 2000 [žiūrèta 2015-01-08]. <http://apps.who.int/gb/archive/pdf_files/ WHA53/ea14.pdf?ua $=1>$.

20. World Healh Organization. Vienna declaration on Nutrition and Noncommunicable diseases in the Context of Health 2020. WHO Ministerial Conference on Nutrition and Noncommunicable Diseases in the Context of Health 2020 [interaktyvus]. 4-5 July 2013, Vienna [žiūrèta 2015-01-08]. <http://www.euro.who.int/_data/assets/ pdf_file/0003/234381/Vienna-Declaration-on-Nutrition-and-NoncommunicableDiseases-in-the-Context-of-Health-2020-Eng.pdf?ua=1>. 
21. World Health Organization. Adelaide statement on health in all policies: moving towards a shared governance for health and well-being [interaktyvus]. 13-15 April 2010, Adelaide [žiūrèta 2015-03-06]. <http://www.who.int/social_determinants/ publications/isa/hiap_statement_who_sa_final.pdf?ua=1>.

22. World Health Organization. Health 2020: a European policy framework supporting action across government and society for health and well-being [interaktyvus]. WHO EUR/RC62/9, 2012 [žiūrèta 2015-01-08]. <http://www.euro.who.int/_data/assets/ pdf_file/0009/169803/RC62wd09Eng.pdf?ua=1>.

\title{
Local Stakeholders' Attitudes towards Effective Health Promotion Policy Measures in Physical Activity and Healthy Eating for Children and Youth
}

\author{
Aldona Jociūtė, Gintarè Petronyte் \\ Mykolas Romeris University, Lithuania
}

Summary. This article focuses on local stakeholders' (policy-makers and decisionmakers, administrators and practitioners) attitudes towards effective health promotion policy measures in physical activity and healthy eating for children and youth. A qualitative study using semi-structured interview method was performed with 12 representatives of the Klaipeda city, Kaunas and Jurbarkas districts municipal institutions in JulySeptember, 2013, implementing the international healthy eating and physical activity in a local communities' project (HEPCOM). Based on the results, stakeholders in planning health promotion activities in physical activity and healthy eating for children and youth mainly apply policy development, strategic planning, action planning and implementation measures, however, they face the use of evaluation measures. The key prerequisites for the development of health promotion activities in physical activity and healthy eating for children and youth at the local communities include targeted health policy strategy and the priorities identified at the national level, inter-institutional cooperation, cross-sectoral activities, the availability of information on best practice interventions and their evaluation tools, as well as human, financial and information resources.

Keywords: health promotion policy, physical activity and healthy eating, stakeholders.

Aldona Jociutè, Mykolo Romerio universiteto Politikos ir vadybos fakulteto Politikos mokslų institutas, biomedicinos mokslų daktarè.

Aldona Jociutė, Mykolas Romeris University, Faculty of Policy and Management, Institute of Political Science, Doctor of Biomedicine Science.

Gintarè Petronyte், Mykolo Romerio universiteto Politikos ir vadybos fakulteto Politikos mokslų institutas, biomedicinos mokslų daktarè.

Gintarė Petronytė, Mykolas Romeris University, Faculty of Policy and Management, Institute of Political Science, Doctor of Biomedicine Science. 